\title{
Identification of bacteria associated with a disease affecting the marine sponge Ianthella basta in New Britain, Papua New Guinea
}

\author{
James M. Cervino ${ }^{1, *}$, Kathryn Winiarski-Cervino ${ }^{2}$, Shawn W. Polson ${ }^{3}$, \\ Thomas Goreau ${ }^{4}$, Garriet W. Smith ${ }^{5}$ \\ ${ }^{1}$ Department of Biological Sciences, Pace University, 1 Pace Plaza, New York, 10038, USA \\ ${ }^{2}$ The New York Academy of Medicine, New York, 10029-5293, USA \\ ${ }^{3}$ Medical University of South Carolina, Charleston, South Carolina, 29425, USA \\ ${ }^{4}$ Global Coral Reef Alliance, 37 Pleasant St., Cambridge, Massachusetts, 02139, USA \\ ${ }^{5}$ Department of Biology and Geology, University of South Carolina, Aiken, South Carolina, 29801, USA
}

\begin{abstract}
Ianthella basta marine sponges in Kimbe Bay, west New Britain, Papua New Guinea were affected by a disease, and exhibited high mortality, between 1996 and 2000. These fan-shaped sponges were mottled with brown lesions, rotted tissue and large holes. The decayed tissue was surrounded by brown biofilm that smothered the ostia openings. Since 1996, I. basta suffered its highest mortality at 3 sites within $16-20 \mathrm{~km}$ of the shore of west New Britain. No mortality was observed at 3 other locations further from shore (between $27-41 \mathrm{~km}$ ), nor at 10 sites located more than $41 \mathrm{~km}$ from shore outside of Kimbe Bay in deeper waters, nor at the site nearest to shore. Comparison of the carbon source utilization patterns of 99 bacterial isolates from all healthy and diseased sponges revealed 5 species of bacteria specifically present in diseased I. basta. These bacteria were not present in healthy sponge samples. Bacteria isolated from affected sponges and inoculated onto healthy sponges caused disease signs similar to those in field specimens. The 16S rRNA genes from these bacteria were sequenced and found to correspond with 2 species of Bacillus and 3 species of Pseudomonas. The closest relatives of these bacteria based on BLAST searches included many terrestrial pathogens and species that are used as pathogens against insects and fungi in integrated pest control management. The bacteria causing disease in $I$. basta may thus originate from pesticides applied to agricultural land, predominantly oil palm plantations, in west New Britain. The possibility that these bacteria can pass virulence factors to marine bacteria through horizontal gene transfer needs to be investigated, as this may have unexpected impacts on marine ecosystems.
\end{abstract}

KEY WORDS: Sponge disease $\cdot 16 \mathrm{~S}$ rRNA $\cdot$ Pseudomonas $\cdot$ Bacillus $\cdot$ Pesticide $\cdot$ Ianthella basta

\section{INTRODUCTION}

Kimbe Bay is located on the northern shore of west New Britain, Papua New Guinea (PNG) $\left(9^{\circ} 48^{\prime} \mathrm{S}\right.$, $\left.147^{\circ} 18^{\prime} \mathrm{E}\right)$. Ianthella basta is found at depths of 10 to $20 \mathrm{~m}$ and grows in dense, localized populations in PNG, Indonesia, Guam, Australia, and the Solomon Islands. These fan-shaped sponges grow to a height of about $1 \mathrm{~m}$ tall and are solid in color. They have been documented as yellow, brown, green, blue, or purple (those studied here are purple). I. basta mortalities have never before been recorded in the literature, but mortalities of other sponge species have been recently reported in the Caribbean (Cervino et al. 2000, Wulff 2000, Webster et al. 2002) and in Algeria, Cyprus, Egypt, Lebanon, Malta, Morocco, Syria, Tunisia, Turkey, Yugoslavia, and the Mediterranean (Vacelet 1994). There has been a visible decline in the abundance and diversity of sponges as well as corals in recent years in some locations around the world (Vacelet 1994, Wulff 2000, 
Webster et al. 2002). Rützler et al. (1988) reported that sponge mortality has been attributed to cyanobacterial infection. Recent reports indicate that temperature stress (Cervino et al. 2004, Goreau \& Hayes 2005) is having a severe impact on important species in tropical coral reef ecosystems, concurrent with an increase in coral and sponge diseases (Goreau et al. 1998, Wulff 2000, Porter et al. 2001, Webster et al. 2002). Because the precise mechanisms of these mortalities have mostly not been identified (Green \& Bruckner 2000), many of these diseases affecting hermatypic corals are currently referred to as syndromes (Goreau et al. 1998). Some of these syndromes have been suggested as being triggered by unusual stresses from natural or man-made causes such as temperature fluctuations, sedimentation, and pollution (Harvell et al. 1999, Cervino et al. 2004). I. basta is one such marine organism that this research found to be affected by a disease.

In 1996 we noticed scattered and sparse lesions on Ianthella basta during a 1996 coral health monitoring survey in west New Britain, the largest island in PNG (Fig. 1). Subsequent monitoring trips in the Kimbe Bay study locations from 1998 to 2000 showed a decline in the health and abundance of $I$. basta. The appearance of this pathology in I. basta is similar to widespread disease in Caribbean Sea fans that is caused by the soil fungus Aspergillus (Smith et al. 1996). This paper documents the bacteria associated with diseased sponges in PNG. The sponge decline corresponds to a decrease in reef fish and coral cover abundance reported in a recently published 8 yr study of Kimbe Bay (Jones et al. 2004).

\section{MATERIALS AND METHODS}

Fieldwork. In August of 1996, 1998, and 2000, 7 inshore and 10 remote reef sites at latitude $5.5^{\circ} \mathrm{S}$ and longitude $150.1^{\circ} \mathrm{E}$ were visited in Kimbe Bay to track the extent of necrosis among the Ianthella basta population and to sample the sponges in order to identify microbes that may be associated with the necrosis. To conduct the surveys, we used the belt transect method while diving with SCUBA. Belt transects allow for an
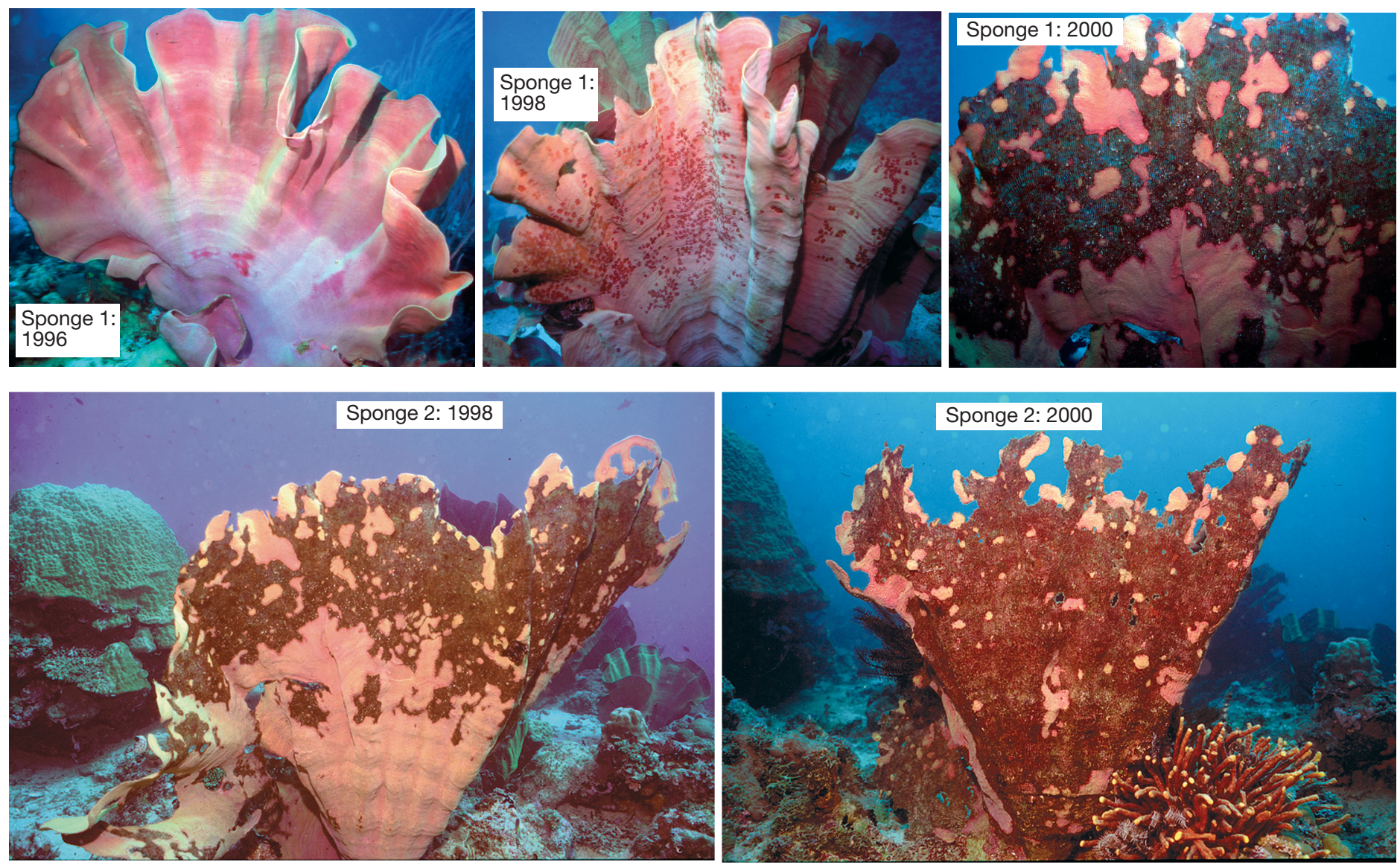

Fig. 1. Two examples of lesions from Ianthella basta taken within Kimbe Bay (Restoff Island) over time 
instantaneous survey of a predefined area within which the number of organisms of interest are recorded. For this research, multiple belt transects of $10 \mathrm{~m}$ in length by $1 \mathrm{~m}$ in width were performed at each reef site wherever sponges were seen over the course of a 45 to 50 min dive. This width is narrow enough for the observer to be able to easily estimate the distances being measured, while allowing for a large enough sample area. Transects were conducted at depths of approximately 3 and $16 \mathrm{~m}$.

To perform the belt transects, a waterproof, tapemeasured line was stretched horizontally at each location where sponges were witnessed. It should be noted that Ianthella basta sponges grow in sparse quantities and in scattered locales compared to many corals and other reef-based organisms. As 1 diver held onto the roll-up tape measure, the other swam forward with the tape at a constant rate for a distance of $10 \mathrm{~m}$, counting the number of healthy and necrotic sponges visible in a $1 \mathrm{~m}$ width and recording the data on an underwater slate. Sponge colonies in Kimbe Bay were photographed in August of 1996, 1998, and 2000 using an Underwater Nikon RS (SLR System). The average lesion size on each affected sponge was measured.

Sponge tissue samples were collected in 2000 using SCUBA. Several types of samples measuring $5 \mathrm{~cm}^{2}$ were cut from the unhealthy sponges using stainless steel scissors. First, samples of both degenerated and healthy sponge tissue were taken from within the circumference of the lesion on affected sponges. Zones of degenerated tissue often contain some healthy tissue within their boundaries. Normal tissue was also cut from the degenerated sponges, from a zone near to, but outside of, the decayed tissue area. Samples were also taken from healthy Ianthella basta sponges with no visible sign of necrosis. At each survey site, 25 samples of normal sponge tissue and 25 samples of affected sponge tissue were collected, all from different sponges. The samples were first placed in plastic Ziploc bags while underwater, then transferred to $100 \mathrm{ml}$ polyethylene bottles containing fresh filtered $(0.5 \mu \mathrm{m})$ seawater and kept in ice coolers. The tissue samples were stored at a temperature of $\sim 2^{\circ} \mathrm{C}$ for future analysis.

Lab work. Researchers placed a $10 \mathrm{ml}$ needle-less syringe next to the sponge's healthy and diseased surfaces and applied gentle suction to collect the surface mucus and possibly particles of necrotic tissue (Fig. 2a,b). Upon surfacing, syringe samples were placed on ice in coolers $\left(2^{\circ} \mathrm{C}\right)$ on the boat. The samples were transferred to media plates with Glycerol Artificial Sea Water (GASW). All samples were transported by airplane while being kept in a cooler. Upon return to the laboratory, samples were re-plated, streaked and separated to obtain pure colonies and incubated on Glycerol Artificial Sea Water (GASW), in duplicate. Plates were then incubated for $72 \mathrm{~h}$ at $28^{\circ} \mathrm{C}$. Bacteria were re-isolated from the plates, chosen to represent the distinct morphological and growth characteristics such as color and colony shapes. Those isolates were then sub-cultured to obtain pure cultures. In total, 99 pure cultures were isolated, 35 originating from control sponge samples (the healthy samples) and 64 originating from diseased sponge samples. A $48 \mathrm{~h}$ agar culture of each isolate was then subjected to Carbon Source Utilization Pattern (CSUP) analysis (Ritchie et al. 2001) in order to cluster bacteria based on their ability to utilize a panel of sole carbon sources. This was accomplished using BIOLOG GN1 96-well MicroPlates

Fig. 2. Sample collection of mucus from a diseased sponge
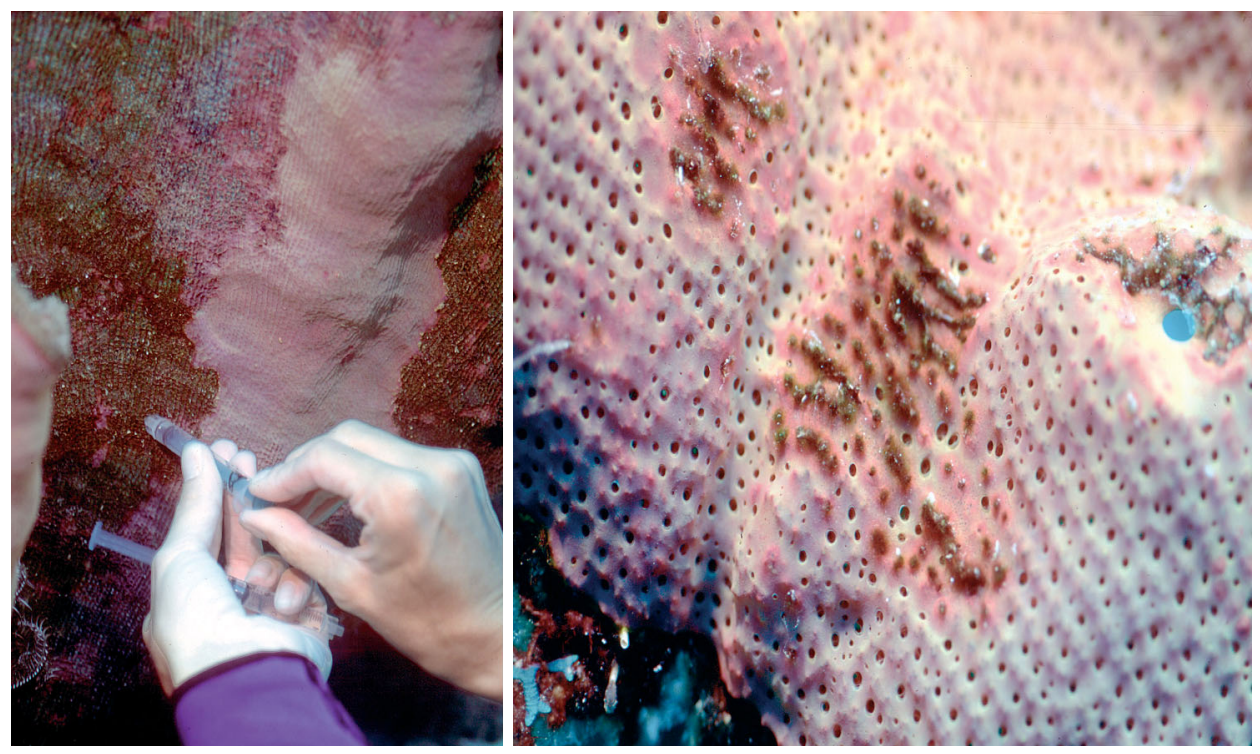
(Biolog 1989). Resulting data from the tests with the isolates from Ianthella basta were organized into a dendrogram using the ML3 BIOLOG software clustering analysis program, MLClust, with default settings.

The 16S of the rRNA gene sequencing was used to identify the microbes from groups of interest (Godfrey et al. 2002). DNA isolation from the bacterial isolates was followed by PCR amplification of the 16S rRNA gene using universal bacteria $16 \mathrm{~S}$ rRNA gene primers: 27F (5'-AGA GTT TGA TCM TGG CTC AG-3') and 1492R (5'-TAC GGY TAC CTT GTT ACG ACT T-3'), and sequenced using primers 27F, 536F (5'-GTG CCA GCM GCC GCG GTA ATW C-3'), 928F (5'-TAA AAC TYA AAK GAA TTG ACG GG-3'), 907R (5'-GCC CCC GTC AAT TCM TTT RAG TTT-3') (Weidner 1996), and/or 1492R. All 16S rDNA sequences were then subjected to BLAST searches of the National Center for Biotechnology Information nucleotide database (Altschul et al. 1997) and Sequence Match analysis using the Ribosomal Database Project's (RDP) database (Cole et al. 2003). The dendrograms displaying phylogenetic positions of bacteria isolated in this study were based on alignment of $1200 \mathrm{bp}$ (Bacillus spp.) and $953 \mathrm{bp}$ (Pseudomonas sp.) of the 16S rRNA gene. Sequence alignments were performed with DNA Star's Lasergene MEGALIGN software (v5.06) using the CLUSTALW method. The tree was generated by the neighbor-joining method (Saitou et al. 1987) with sequence dissimilarity determined by the method of Jukes \& Cantor (1969) using MEGA3 software (v3.1). Boot-strap values are based on 500 replicates. Reference strain sequences were obtained from the RDP (Cole et al. 2003). The $16 \mathrm{~S}$ rRNA sequences generated during this project were deposited in GenBank and assigned accession numbers as follows: SDC2A (DQ323743, DQ323744), SDG1A (DQ323745), SDA3A (DQ323746), SDA21A (DQ323747), and SDB21A (DQ323748).

Infection experiments. Six healthy sponge samples were collected at $3 \mathrm{~m}$ depth in Kimbe Bay and immediately brought back to Mahonia Na Dari research laboratory and placed in $750 \mathrm{l}$ tanks for $2 \mathrm{~d}$ to monitor the health of the sponges. Each aquarium was filled with fresh seawater and temperatures were kept constant at $27^{\circ} \mathrm{C}$. Sponges were held at the bottom of the aquaria with clothespins and mounted to stay weighted down at the bottom of the aquarium tank. Water quality was monitored and kept within the following ranges: temperature of $27 \pm 2^{\circ} \mathrm{C}$, $\mathrm{pH}$ of 8.1 to 8.3 , salinity of $35 \pm 2 \mathrm{~g}$ $\mathrm{l}^{-1}$, and dissolved oxygen of $8.0 \pm 0.1 \mathrm{mg} \mathrm{l}^{-1}$. Filtration was conducted using biological/mechanical 'box' type filters. Inoculation experiments were commenced on the third day. Single-isolate inoculation tests were not successful in showing the disease signs; therefore, all bacterial inoculations included the 5 bacterial species during the second trial. Bacterial isolates were cultured on GASW media and then transferred to small, $2 \mathrm{~cm}$ cut-triangles of fresh media. Each triangle contained all 5 species. No bacteria were swabbed onto the control media. Each media triangle was held on the sponge surface for $72 \mathrm{~h}$, attached with a needle and thread. Each of the 6 sponges had 4 triangles on them, 2 had no bacteria (representing controls), and the other 2 had the 5 bacteria swabbed onto the media triangle (Fig. 3).

\section{RESULTS}

Field observational data from 1996, 1998, and 2000 show that the sponge infections spread increasingly further within and between sponges as time passed. Seven study sites in Kimbe Bay were visited in each of the $3 \mathrm{yr}$ for which data were collected. They are as follows with their repective distances from shore: Christine's Reef, 15 km; Restoff Island, 16 km; Vanessa's Reef, 17 km; Jeffrey's Reef, 20 km; Inglis Shoal, 27 km; Joelle's Reef, 32 km; and Kimbe Island, 41 km (Fig. 4). An additional 10 dive sites located more than $41 \mathrm{~km}$ from shore (beyond Kimbe Island) were visited in 1998, and Ianthella basta sponges there showed no signs of necrosis.

Of the 7 sites visited within Kimbe Bay during 1996, only 4 of 28 sponges exhibited lesions (14\%). The average lesion size was $0.11 \pm 0.28 \mathrm{~cm}^{2}$ (Fig. 5). During 1998, many more holes or lesions were observed on sponges at 3 study sites close to shore. The average lesion size was much larger than in 1996, increasing to $6.48 \pm 3.69 \mathrm{~cm}^{2}$ on average (Fig. 5). The lesions develop within a biofilm and tangled mat of filamentous cyanobacteria (Fig. 6). Upper edges and large central zones on degenerated sponges appeared rotted, with thinned lattice, brown discoloration, and in some cases with purplish blue cyanobacteria filaments. The most

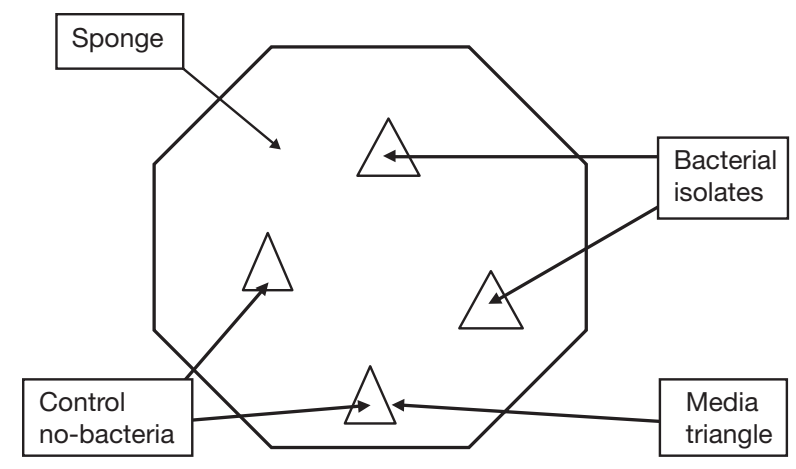

Fig. 3. Sponge sample and inoculation trials showing control inoculation and bacterial inoculation 


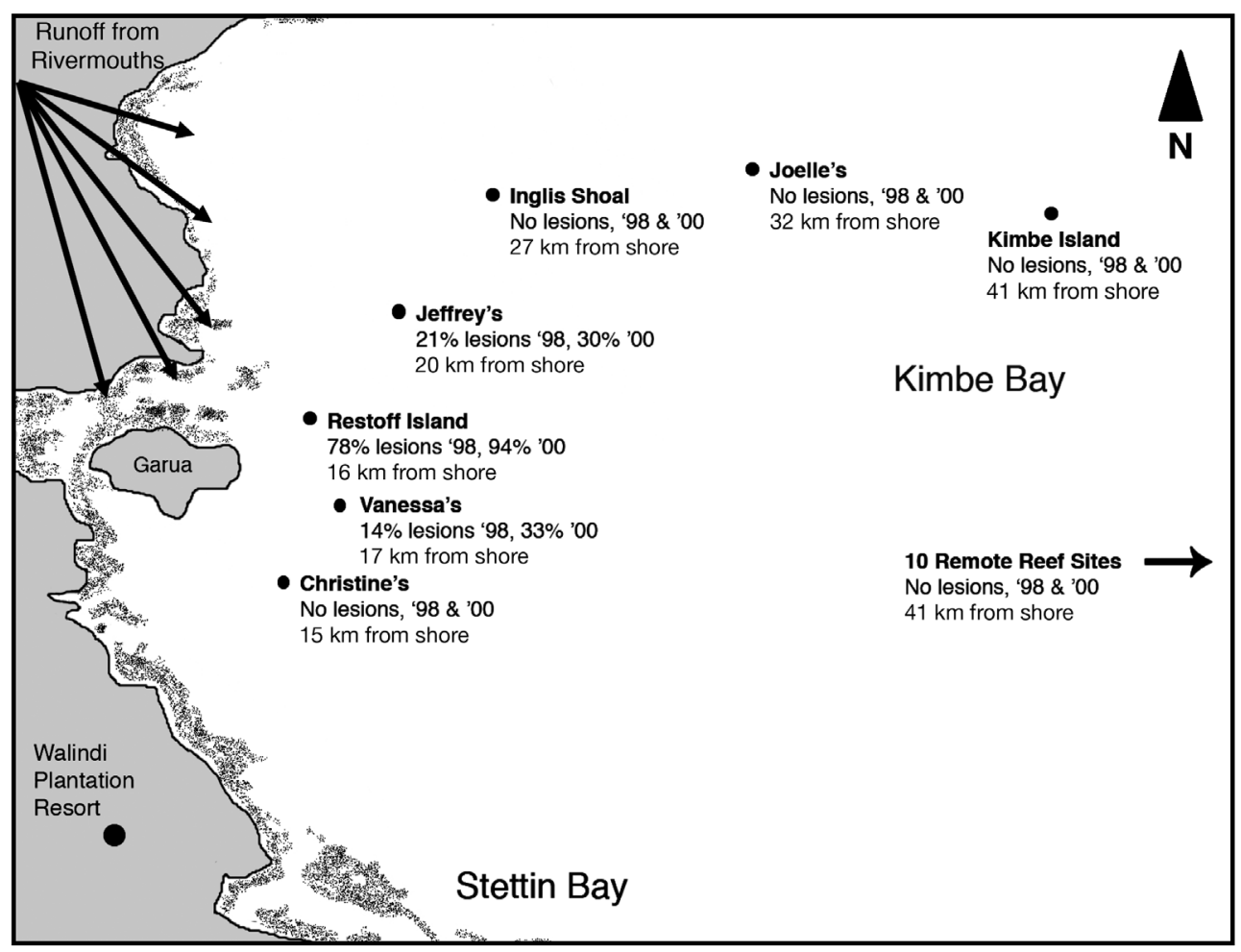

Fig. 4. Kimbe Bay, New Britain. Location of 7 in-shore and 10 reef sites monitored and sampled for this study between 1996 and 2000. Details of percentages of sponges with lesions by year and distance from shore are given for each site

severely affected sites observed in 1998 were: Restoff Island $(78 \%$ of the sponges had lesions, or 32 of 41 sponges counted in 5 transects); Jeffrey's Reef $(27 \%$ with lesions, or 20 of 93); and Vanessa's Reef (15\% with lesions, or 13 of 88) (Fig. 7). No lesions were evident on Ianthella basta at reef study sites located more than $20 \mathrm{~km}$ from shore.

By August 2000, tissue decay was evident on a larger quantity of Ianthella basta sponges at reefs within $20 \mathrm{~km}$ of shore. Lesions became more prevalent at Restoff Island, Vanessa's Reef and Jeffrey's Reef. At Restoff, $94 \%$ of I. basta had lesions (48 of 51); at Vanessa's, $33 \%$ of I. basta had lesions (31 of 94); and at Jeffrey's, $30 \%$ of $I$. basta had lesions (31 of 105). As of 2000 , the average lesion size had increased to $36.39 \pm$ $16.54 \mathrm{~cm}^{2}$ (Fig. 7). No lesions appeared on I. basta at the 4 other reef sites, 3 of which were located further from shore than the impacted reefs (Inglis Shoal, 27 km; Joelle's Reef, 32 km; and Kimbe Island, 41 km). Unexpectedly, no lesions were found on I. basta at Christine's Reef, which is closer to shore (15 km) than the other reef study sites. Reports from Mahonia Na Dari Research Center, a scientific research facility located on the Kimbe Bay shoreline, indicate that $I$. basta sponges located at these 4 unaffected reefs remained healthy throughout 2000, with no lesions appearing on their surfaces.

\section{Bacterial isolates}

Carbon Source Utilization Pattern (CSUP) analyses of the bacterial isolates revealed 3 groups of bacteria present in diseased samples of Ianthella basta, that were not represented in healthy sponge samples (Fig. 8). These 3 metabolic groupings were termed B, I, and $\mathrm{J}$ based on their positions on the CSUP dendrogram. Groups I and J were found in 4 isolates each and, despite being clustered next to each other on the

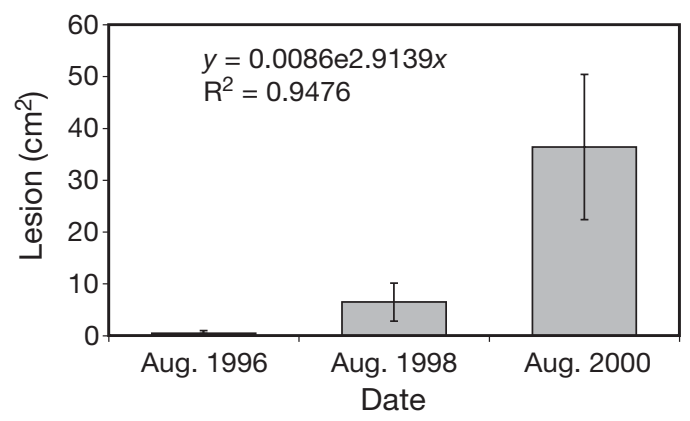

Fig. 5. Ianthella basta. Average size of lesions at the study sites where sponge disease was detected. Lesions grew from $0.107 \mathrm{~cm}^{2}$ in 1996 , to $6.47 \mathrm{~cm}^{2}$ in 1998 , to $36.39 \mathrm{~cm}^{2}$ in 2000 . In 1996 , lesions were detected only on sponges at Restoff Island. In 1998 and 2000, lesions were detected at 3 study sites (Restoff, Vanessa's and Jeffrey's), and the average lesion size had increased dramatically by 2000 


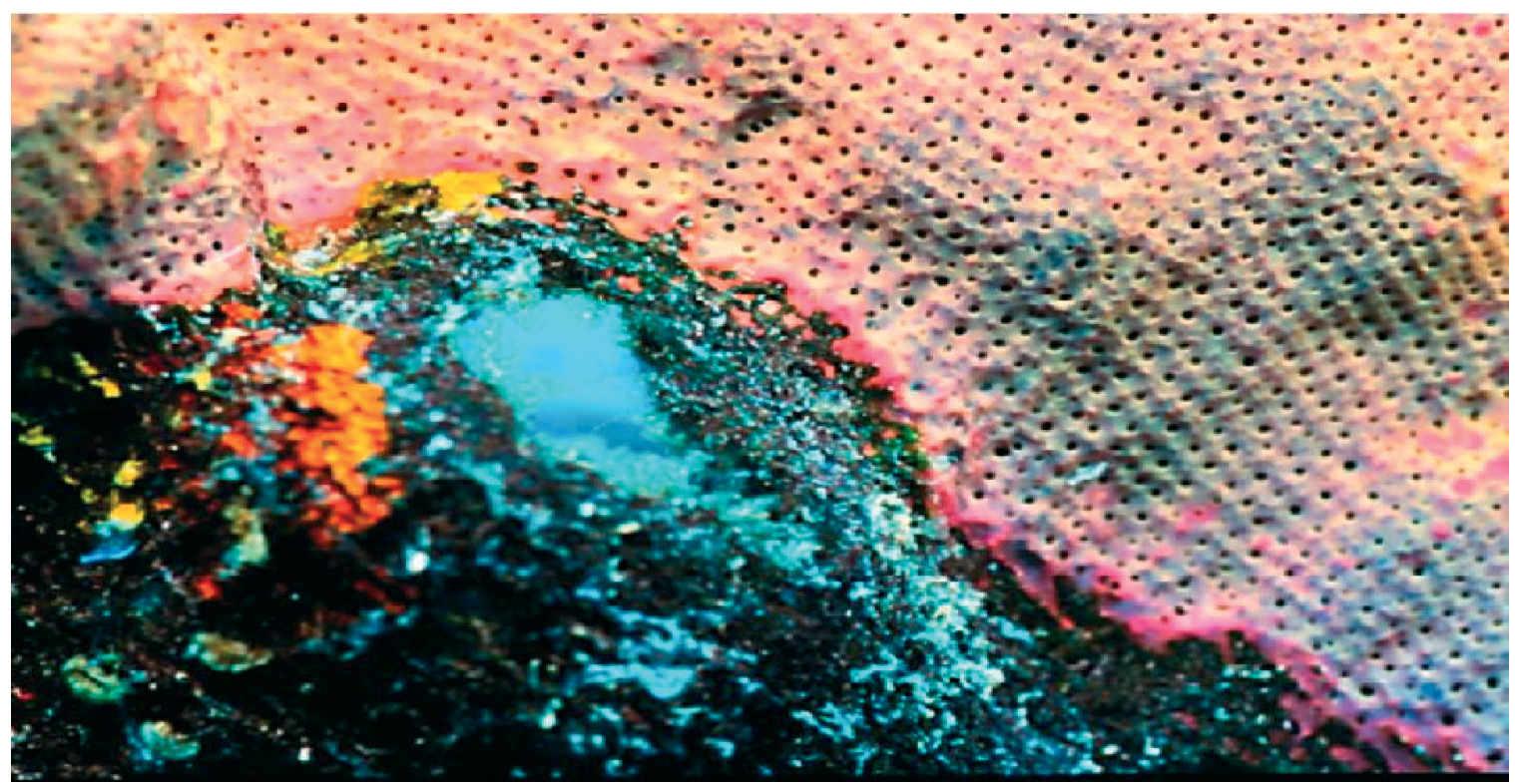

Fig. 6. Ianthella basta. Detail of lesions around the ostial pores

dendrogram, share only $\sim 20 \%$ metabolic similarity. Group B is remote from both groups I and J, sharing only $\sim 2 \%$ similarity with those groups, and was present in 11 isolates (Table 1).

Sequencing of the 16S rRNA genes from 5 bacterial isolates belonging to Groups B, I, and J showed that they correspond with the genera Bacillus, which is ubiquitous in the environment, and Pseudomonas, which is common in many habitats including soil and water. The closest bacterial strain matches, when compared to the Ribosomal Database Project II at Michigan State University (Cole et al. 2003) using Sequence Match Analysis, are as follows:

(1) Isolate SDG1A: Pseudomonas sp. SMCC DO715. SDGIA hails from the $J$ group as identified in the CSUP analyses (Fig. 9).

Table 1. Ianthella basta. Number of bacterial isolates and the percentage of healthy vs. diseased in each metabolic grouping. Groups in bold are putative isolates (see Fig. 8)

\begin{tabular}{|lccc|}
\hline Group & Total isolates & Healthy $(\%)$ & Diseased (\%) \\
\hline A & 1 & 100 & 0 \\
B & $\mathbf{1 1}$ & $\mathbf{0}$ & $\mathbf{1 0 0}$ \\
C & 8 & 38 & 63 \\
D & 22 & 41 & 59 \\
E & 7 & 71 & 29 \\
F & 4 & 25 & 75 \\
G & 12 & 42 & 58 \\
H & 12 & 42 & 58 \\
I & $\mathbf{4}$ & $\mathbf{0}$ & $\mathbf{1 0 0}$ \\
J & $\mathbf{4}$ & $\mathbf{0}$ & $\mathbf{1 0 0}$ \\
K & 2 & 50 & 50 \\
L & 12 & 42 & 58 \\
Total & 99 & 37 & 63 \\
\hline
\end{tabular}

(2) Isolate SDC2A: Pseudomonas pseudoalcaligenes. SDC2A is a member of the B group (Fig. 9).

(3) Isolate SDA21A: Pseudomonas sp. MBIC2027. SDA21A is a member of the B group (Fig. 9).

(4) Isolate SDB21A: Bacillus cereus, thurengiensis/ anthracis. SDB21A is a member of the B group (Fig. 10).

(5) Isolate SDA3A: Bacillus pumilus. SDA3A is a member of the I group (Fig. 10).

Infection experiments from the 2 sponges revealed paling of the sponge tissue as seen during thermal bleaching in 2 out of the 6 sponges. The remaining sponges showed necrotic decay similar to field specimens. However, complete holes or openings were not established during the course of this experiment. Ostial openings were smothered with brown mucus surrounded by blue-green algae. The control triangles showed no signs of disease. Trying different combinations of the bacteria was not an option due to time con-

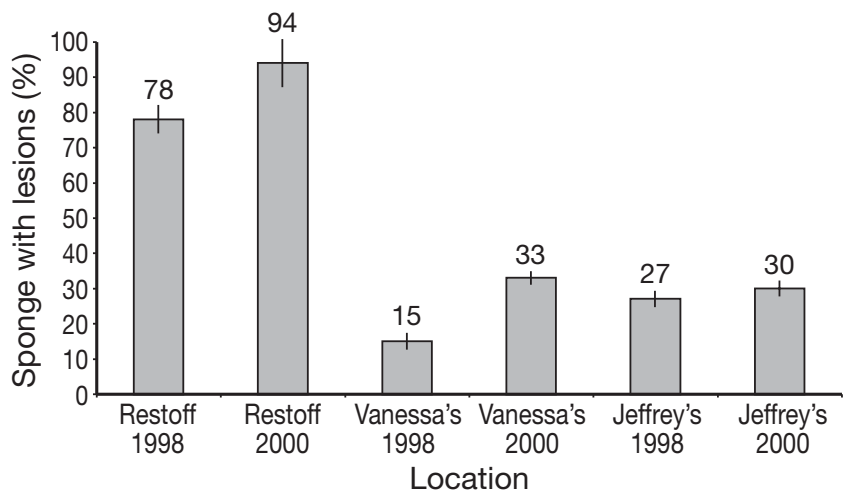

Fig. 7. Ianthella basta. Time series of disease progression between 1996 and 2000 


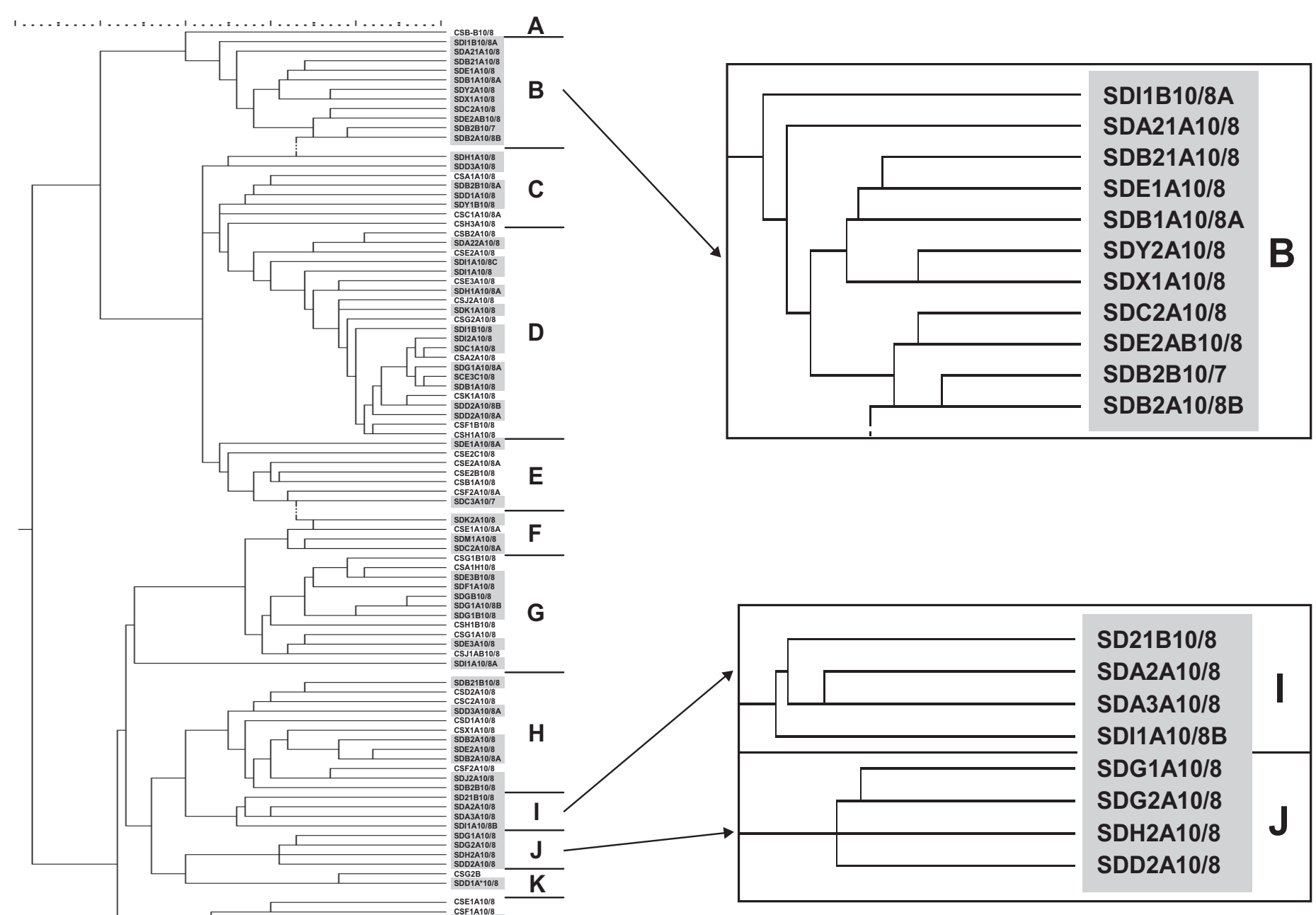

$L$

Fig. 8. Dendrogram constructed from carbon source utilization patterns. Each item in the dendrogram represents a bacterial isolate. Isolates shaded light gray were from diseased samples. All other samples are from healthy sponges

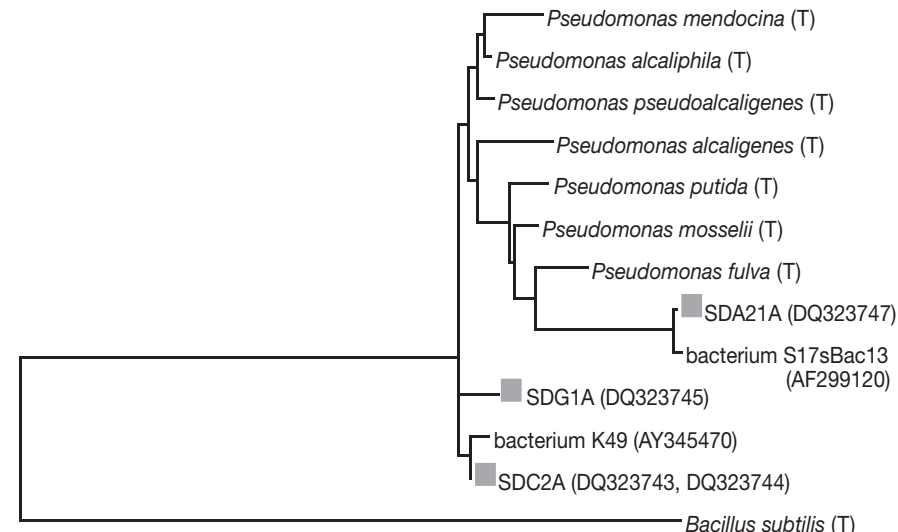

Fig. 9. NCBI accession numbers of non-type strains are parenthetically noted. Strains isolated in this study ( $\square$ ); Type strains (T). Dendrogram showing the results of 16S rRNA gene sequencing of bacterial isolates from Bacillus spp. Phylogenetic positions of these putative pathogens isolated in this study are based on 16S rRNA gene sequence

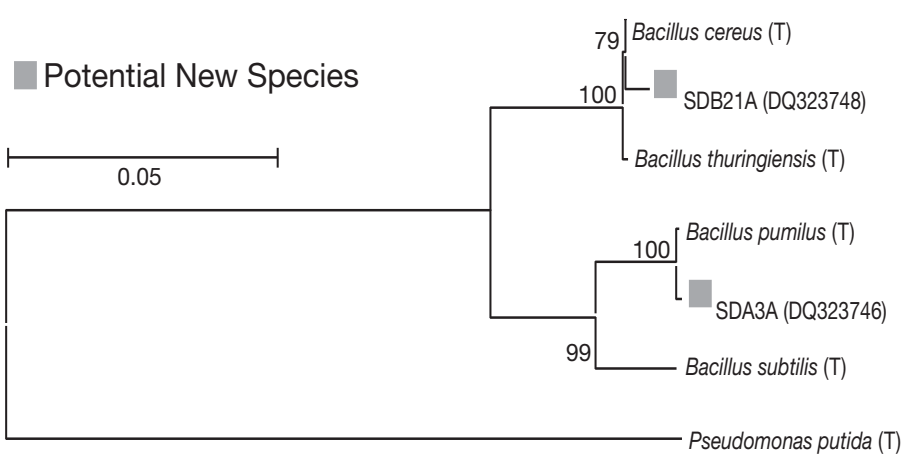

Fig. 10. NCBI accession numbers of non-type strains are parenthetically noted. Strains isolated in this study ( $\square)$; Type strains (T). Dendrogram showing the results of 16S rRNA gene sequencing of bacterial isolates from Pseudomonas spp. Phylogenetic positions of these putative pathogens isolated in this study are based on $16 \mathrm{~S}$ rRNA gene sequence 
straints and weather conditions. Therefore, since we were not able to obtain results using single isolates within $48 \mathrm{~h}$, we immediately applied all 5 bacterial groups together. There was no opportunity to reisolate the bacteria that caused the lesions in aquaria, and DNA comparison of bacterial communities were not sampled and re-tested. Therefore, these results show only infectivity and are not complete confirmation of Koch's postulates. Samples were brought back to the University of South Carolina Coral Pathology laboratory for further testing; however, all specimens were in advanced stages of stress, preventing further re-testing of this experiment for accurate analysis.

\section{DISCUSSION}

\section{Environmental patterns and disease}

The inner fringing reefs of southwestern Kimbe Bay are being subjected to various stress factors that cause coral reef decline, including sedimentation, algal overgrowth, and rising sea surface temperatures. The inner reefs are particularly impacted by river-transported sediments and fertilizer, which enter the waterways from land that is being increasingly deforested and developed for palm oil plantations (S. Seeto pers. comm.). The inshore fringing reef area is quite turbid and muddy as a result, and a high sediment load covers barrel sponges and corals on the reefs closest to land. The sediment and algal abundance are much lower on the land-facing side of the offshore bank reefs, located only 50 to $100 \mathrm{~m}$ offshore; and are nearly absent on the seaward side of those banks.

Between 1996 and 2000, lesions on Ianthella basta and die-offs of those sponges increased by $90 \%$ at Restoff Island. The bases of the sponges, or 'holdfasts', appeared wilted and unable to support their structures. Although the focus of this research was I. basta, degenerated tissue witnessed on other sponge species is relevant. Degenerated tissue and sponge bleaching was also seen on the undersides and bases of Jaspis sp., Xestospongia sp. and X. testudinaria (Haplosclerida) at all locations. Upper portions of these sponges appeared normal but their bases were rotted away. Sponge bleaching was also seen during September 1998, coincident with coral bleaching (J. M. Cervino \& T. Goreau pers. obs.).

It is worth noting that 2 of the affected sites closest to shore (Restoff and Vanessa's) experienced the largest increase in degenerated sponges between 1998 and 2000. Observations of a less dramatic increase in degenerated sponges at some of the other study sites (Jeffrey's Reef), and a lack of increase at the remaining sites, support a possible link between sponge disease prevalence and proximity to shore. The one exception to that theory during this research was the absence of diseased sponges at Christine's Reef, the study site closest to shore. A confluence of 3 rivers that flow into Kimbe Bay may be a source of land-derived bacteria and pollutants for near-shore habitats (Fig. 4). We hypothesize that the ocean current patterns are taking the effluent north of Christine's reef, which is the furthest south of all the study sites. This is one explanation for why no diseased sponges were found there. However, ocean current patterns for this specific area have not been directly determined.

\section{Bacterial isolates}

We studied the 3 distinct groups of bacteria that we found to be specific to the diseased samples of Ianthella basta, to investigate their possible role as pathogenic agents. Each bacterial isolate from the diseased sponge samples belonged to 1 of 3 CSUP Groups: 11 isolates belonging to CSUP Group B, 4 belonging to CSUP Group I, and 4 belonging to CSUP Group J. CSUP Group B included the genera Bacillus and Pseudomonas, CSUP Group I included the genus Bacillus, and CSUP Group $\mathrm{J}$ included the genus Pseudomonas. Interestingly none of the diseased samples had more than 1 bacterial pathogen group present: diseased samples that tested positive for Group B bacteria, for example, did not show the presence of bacteria from either Group I or J (Fig. 8). Still, the possibility that multiple pathogens may be acting in tandem to cause symptoms in I. basta should not be ruled out. Black Band disease of scleractinian corals has been shown to be caused by a consortium of microorganisms (Richardson 1996, Richie et al. 2001). A consortium of 4 unidentified Vibrio sp. was also found to induce the signs of yellow blotch/band disease in corals in the Caribbean Sea (Cervino et al. 2004).

\section{Bacillus}

Members of 2 bacterial genera were isolated only from diseased sponges, Bacillus and Pseudomonas. Bacillus is a genus of Gram-positive bacteria that are ubiquitous in soil, water, and airborne dust. They are also common in marine habitats (Johnson et al. 1994, Ivanova et al. 1999). Two Bacilli were isolated as possible pathogens from degenerated tissue of Ianthella basta infected tissue (Fig. 9). The first Bacillus isolated from diseased sponges was most closely related to the $B$. cereus group, which includes several species of bacteria which are closely related and difficult to differentiate, including $B$. cereus, $B$. thuringiensis, $B$. anthracis, and B. mycoides. This motile 
bacterium is also found in marine samples (Kobayashi et al. 2004). Strains of B. cereus are used as pesticide to kill mosquitoes (Finlay et al. 1999). Another member of the $B$. cereus group, $B$. thuringiensis (Bt), is widely used in a broad-spectrum insecticide spray, and genetically engineered into plants to control pests (Hofte \& Whiteley 1989, Lereclus et al. 1993, Huang et al. 1999). Bt is widely claimed to be a 'natural' and 'safe' insecticide and is commonly sprayed on a wide variety of crops to control insect pests (Baum et al. 1999). It is specifically recommended to control the major insect pest in oil palm plantations (Hoong et al. 1992), which occupy much of the lowland areas of New Britain. Bt bacterium is claimed to be safe because it only attacks specific insect pests (Syed \& Shah 1976, Bledsoe et al. 2004) by producing a crystal protein toxin that kills the cells lining the gut of susceptible insects. However, recent evidence shows that Bt affects a wide variety of invertebrates, including crustaceans and nematodes (Ivanova et al. 1999, Helgason et al. 2000), and that Bt persists in soils and in waters (Jensen et al. 1994). It is therefore not surprising that if terrestrial insecticide sprays containing Bt are leached into Kimbe Bay, I. basta and other marine invertebrates might be affected.

The second strain of Bacillus sp. isolated from infected Ianthella basta showed closest homology to $B$. pumilus, which is also found commonly in soils. Strains of $B$. pumilus are used as a fungicide on many crops including soybeans (Ouoba et al. 2003). It is very interesting that both Bacillus strains associated with our diseased sponges are often used for agricultural pest control. This is especially pertinent to this study because the diseased and dying sponges were located in such close proximity to agricultural activity sites and to river mouths that drain farmed land. While further studies are recommended to track the sources of the bacteria, anthropogenic introduction via agricultural activities seems a convincing potential source.

\section{Pseudomonas}

Members of the genus Pseudomonas form part of a large, heterogeneous and ubiquitous group of highly versatile, metabolically bioactive colonizers of surfaces. Pseudomonads are Gram-negative chemoorganotrophs. Many strains are bioactive, fast-growing and are able to suppress or out-compete pathogenic and other deleterious microorganisms. Pseudomonas species are also opportunistic invaders of plants, and cause blight disease in bean plants as well as lethal blight in palms, inducing slow soft rot in plant tissue upon inoculation (Willis et al. 2001).

Three types of Pseudomonas were isolated only from diseased tissue (Fig. 7b). The first isolate is very close to $P$. alcaliphila, found in cold marine waters (Yumoto et al. 2003). It is also closely related to $P$. mendocina and P. pseudoalcaligenes, which are found in soils and waters and used in the degradation of aromatic hydrocarbons as well as being a bivalve and human pathogen (Lodeiros et al. 1992, Wang et al. 2001). The next closest relatives are the second Pseudomonas isolated from Ianthella basta diseased tissue and strain K49 (Wei et al. 1995). The consortium or interactions between bacterial species are similar to bacterial hrp genes, which encode a large set of regulatory proteins broadly conserved among plant and animal pathogens and constituting a type III secretion pathway known as the 'Hrp pathway' in phytopathogenic bacteria (Kim et al. 1997). It is also important to note that at least 2 proteins secreted via the Hrp pathway hrp genes are present in all gram-negative necrogenic plant pathogens and are created by transposon mutagenesis of Pseudomonas syringae (Bogdanove 2002). This leads to rapid tissue necrosis at the site of the pathogen, as appears to be occurring with I. basta. The kin group to the above strain is comprised of $P$. alcaligenes, a very common marine bacterium (Lorenz \& Sikorski 2000) including forms that are toxic to fish (Kobayashi et al. 2004), shrimp, and scallops (Alavandi et al. 2004); P. fulva, found in leaf litter on soils (Luz et al. 2003) and used in fungicide sprays on rice and other crops (Xie et al. 2003); and $P$. putida and other Pseudomonas spp., which are also used as anti-fungal sprays and have forms that cause tomato disease (Pedley et al. 2004) and are used for biodegradation of DDT (Kamanavalli et al. 2004). The third Pseudomonas isolate belonged to a more distantly related group. It was related only to an uncultured bacterium, S17 sBac13m, for which no further information was found.

Pseudomonas species thrive under moist conditions in soil, particularly in association with plants, as well as in sewage sediments and aquatic environments (Madigan et al. 1997). Surface water runoff and wind currents are among the environmental conditions that may affect the dissemination of Pseudomonas species. For example, conditions of high humidity and temperature (80 to $90 \%$ humidity, $27^{\circ} \mathrm{C}$ ) favored the colonization of this species on lettuce and bean plants (OECD 1997). While the marine environment is hostile to many terrestrial microbial pathogens and will cause most to rapidly die off, as seen in the Great Barrier Reef (Webster et al. 2002), some of these pathogens may accumulate in filter-feeding organisms such as sponges (Webster et al. 2002, J. Lopez pers. comm.). In marine waters, species of Pseudomonas and other bacterial families have been detected in elevated numbers during fish kills associated with red tides (www. ukmarinesac.org.uk/index.htm). 


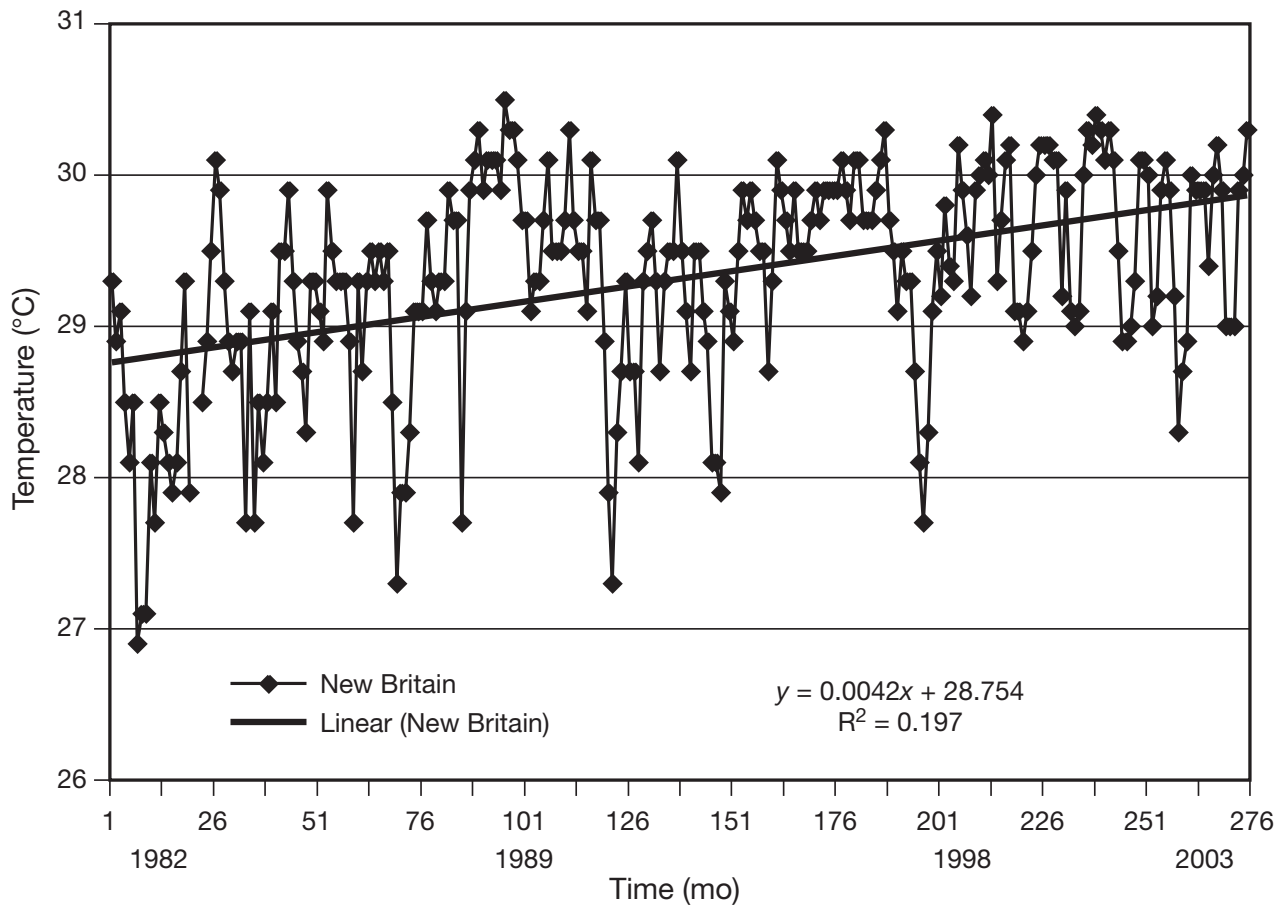

Fig. 11. Monthly average satellite-derived sea surface temperatures for Kimbe Bay, 1982-2003 from Goreau \& Hayes (2005). The hottest years during this period were 1989 and 2001. The regression line and equation show an increase in average temperature over the entire data record. El Niño years are marked by cooler water in the West Pacific, so the increase in mean temperature is linked to global warming and not El Niño events (Goreau \& Hayes 2005)

\section{Temperature}

A temperature increase has occurred in PNG waters as shown in satellite-derived sea surface temperature records of Kimbe Bay, studied since 1982 (Goreau \& Hayes 2005) (Fig. 11). Recent overall coral mortality of offshore reefs at Kimbe Bay was estimated to be in the range of 10 to $20 \%$ in 2001, based on filmed transects of numerous sites during this study, and much of this may be due to bleaching events. A coral bleaching-like syndrome that correlates with temperature stress may also be caused by, or associated with, pathogens (Ben-Haim et al. 2003, Cervino et al. 2004). These coral diseases are more virulent and faster spreading at high temperatures (Cervino et al. 2004). Some of the sponge die-offs may be similarly linked to local temperature stress, or may be due to the dissemination of novel or newly adapted pathogenic agents in the aquatic environment (Vacelet 1994, Goreau et al. 1998, Harvell et al. 1999) or a combination of both pathogens and elevated temperature and nutrient enrichment (LaPointe et al. 1992, Ben-Haim et al. 2003, Cervino et al. 2004). Jones et al. (2004) recently conducted an 8 yr study which indicated that over $75 \%$ of reef fish species declined in abundance in Kimbe Bay in what the authors term a catastrophic decline, and showing that $50 \%$ of reef fish species declined to less than half of their original numbers. Field research also showed that there has been a decline in scleractinian coral cover from $66 \%$ in 1996 to a low of $7 \%$ in 2002. This corresponds to the time of our study (1996-2000). The authors also point out that this decline is attributed to anthropogenic habitat degrada- tion as a result of pollution and thermal bleaching events. However, we note that Jones et al. (2004), studied only inshore fringing reefs, and did not examine the offshore reefs sites investigated in this Ianthella basta study. We note that the live coral cover in offshore reefs was an order of magnitude higher than that of the inshore reefs reported by Jones et al. (2004), and that our estimates of cover on inshore fringing reefs is similar to theirs. We therefore concur with Jones et al. (2004) that marine reserves are not by themselves an effective management strategy for protecting coral reefs and marine biodiversity from large-scale pollution or global warming.

\section{Future work}

The findings of this paper suggest that the bacteria causing Ianthella basta disease may be closely related to pathogenic terrestrial bacteria, some of which are widely applied in land-based agricultural activities. Direct tests of the possible links to land-based sources of pollution as well as to climate change need to be conducted. Future research will test pathogenicity of various isolates or combinations of isolates from the groups of putative pathogens that we have identified in infected tissues, followed by re-culture and sequencing of these isolates. The putative pathogens will be tested on healthy sponges in attempt to fulfill the requirement of Koch's postulates (Koch 1882) in its completion; to date, we have only satisfied infectivity of the bacteria isolated from diseased sponges. The 
potential inability to culture putative pathogens to satisfy Koch's postulates should not prevent the pathology of $I$. basta from being classified as a disease, if a disease is defined as any impairment, interruption, cessation, proliferation or other disorder of vital cellular functions, systems or organs (Willis et al. 2001).

\section{CONCLUSION}

Microbiological analyses have shown that 5 distinct bacteria in the Bacillus and Pseudomonas families are strongly correlated with a disease that spread through the Ianthella basta sponge population in west New Britain, PNG from 1996 through 2000. Die-offs of $I$. basta may have increased during periods of elevated sea-surface temperatures. The die-offs were most abundant on reefs close to shore. Therefore, we speculate that land deforestation activities, bacterial pesticide pollution from agriculture, and thermal bleaching events may have introduced new pathogenic bacterial strains that affected marine sponges, allowing invasive cyanobacterial communities to flourish on the sponges' ostial surfaces. A common pattern was seen in the 2 Bacillus species and 3 Pseudomonas species isolated only from diseased sponge tissue. They were closely related to species that are known to be human pathogens, or that are widely used as pesticides and sprayed on many agricultural crops, including oil palms. These species were also closely related to known marine pathogens affecting fish and invertebrates. It is possible that horizontal gene flow from terrestrial species, some pathogenic to many organisms (Helgason et al. 2000, Lorenz \& Sikorski 2000) and used as wide-spectrum pesticides, could occur into related marine species that could then infect marine invertebrates. If so, the allegedly 'safe natural' insecticides widely used in Integrated Pest Management could be having serious and unanticipated effects in marine ecosystems. These possible connections need to be thoroughly examined in future research.

Acknowledgements. We thank Max Benjamin, of Walindi Plantation Resort in Kimbe Bay, Papua New Guinea, for invaluable accommodations and logistical support, access to the study sites and shared anecdotal knowledge of changes on the reef. We thank Shannon Seeto of Mahonia Na Dari for logististical support, and discussions. We are grateful for their friendship and assistance year after year. Thanks to Alan Raabe, captain of the MV 'FeBrina' in Papua New Guinea, for supporting our exploration of the outer reefs of Kimbe Bay. Thanks also to Dr. Raymond Hayes of the Global Coral Reef Alliance for reviewing the satellite-derived sea surface temperature data and assisting in critical analyses. Special thanks to Dr. Matthew Draud, Chairman of the Biology Department at Long Island University, for carefully editing this manuscript and offering suggestions that improved its quality. Thanks to
Deborah Winiarksi for her assistance with graphic design. Thanks to The New York Academy of Medicine for supporting this research during 2004.

\section{LITERATURE CITED}

Alavandi SV, Vijayan KK, Santiago TC, Poornima M, Jithendran KP, Ali SA, Rajan JJ (2004) Evaluation of Pseudomonas sp. PM11 and Vibrio fluvialis PM17 on immune indices of tiger prawn, Penaeus monodon. Fish Shellfish Immunol 17:115-120

Altschul SF, Madden TL, Schäffer AA, Zhang J, Zhang Z, Miller W, Lipman DJ (1997) Gapped BLAST and PSIBLAST: a new generation of protein database search programs. Nucleic Acids Res 25:3389-3402

Baum JA, Johnson TB, Carlton BC (1999) Bacillus thuringiensis: natural and recombinant bioinsecticide products. In: Hall FR, Menn JJ (eds) Biopesticides: use and delivery. Humana Press, Totowa, NJ, p 189-210

Ben-Haim Y, Zicherman KM, Rosenberg E (2003) Temperature-regulated bleaching and lysis of the coral Pocillopora damicornis by the novel pathogen Vibrio coralliilyticus. Appl Environ Microbiol 69:4236-4242

Biolog (1989) GN MicroPlate: instructions for use. Biolog, Hayward, CA

Bledsoe SD, Harmon PF, McGovern RJ (2004) Professional disease management guide for ornamental plants. Plant Pathology Department, Cooperative Extension Service, Institute of Food and Agricultural Sciences, University of Florida, Gainesville, FL. Available at: http://edis.ifas.ufl.edu

Bogdanove AJ (2002) Protein-protein interactions in pathogen recognition by plants. Plant Mol Biol 50:981-989

Cervino JM, Winiarski K, Polson SW, Smith GW (2000) Sponge disease affecting Ianthella basta in New Britain (Papua New Guinea). Proc 9th Int Coral Reef Symp, Abstract

Cervino JM, Polson SW, Polson SJ, Hayes R, Goreau TJ, Smith GW (2004) Vibrio spp. infection and elevated temperatures as links to Yellow Blotch/Band Disease in the Caribbean. Appl Environ Microbiol 70:6855-6864

Cole JR, Chai B, Marsh TL, Farris RJ and 7 others (2003) The ribosomal database project (RDP-II): previewing a new autoaligner that allows regular updates and the new prokaryotic taxonomy. Nucleic Acids Res 31:442-443

Finlay WJ, Logan NA, Sutherland AD (1999) Semiautomated metabolic staining assay for Bacillus cereus emetic toxin. Appl Environ Microbiol 65:1811-1812

Godfrey SA, Harrow SA, Marshall JW, Klena JD (2002) Characterization by $16 \mathrm{~S}$ rRNA sequence analysis of pseudomonads causing blotch disease of cultivated Agaricus bisporus. Appl Environ Microbiol 67:4316-4323

Goreau TJ, Hayes R (2005) Global coral reef bleaching and sea surface temperature trends from satellite-derived hotspot analysis. World Resource Rev 17:282-321

Goreau TJ, Cervino JM, Goreau M, Hayes RL and 14 others (1998) Rapid spread of Caribbean coral reef diseases. Rev Biol Trop (Suppl) 46(5):157-171

Green E, Bruckner AW (2000) The significance of coral disease epizootiology for coral reef conservation. Biol Conserv 96:347-361

Harvell CD, Kim K, Burkholder J, Colwell RR and 9 others (1999) Emerging marine diseases, climate links and anthropogenic factors. Science 285:1505-1510

Helgason E, Okstad OA, Caugant A, Johansen HA, Fouet A, Mock M, Hegna I, Kolsto AB (2000) Bacillus anthracis, 
Bacillus cereus, and Bacillus thuringiensis-one species on the basis of genetic evidence. Appl Environ Microbiol 66:2627-2630

Hofte H, Whiteley HR (1989) Insecticidal crystal proteins of Bacillus thuringiensis. Microbiol Rev 53:242-255

Hoong HW, Hoh-Christopher KY (1992) Major pests of oil palm in Sabah. The Planter (Malaysia) 68(793):193-210

Huang F, Buschman LL, Higgins RA, McGaughey WH (1999) Inheritance of resistance to Bacillus thuringiensis toxin (Dipel ES) in the European corn borer. Science 284:965-967

Ivanova EP, Vysotskii MV, Svetashev VI, Nedashkovskaya OI and 6 others (1999) Characterization of Bacillus strains of marine origin. Int Microbiol 2:267-271

Jensen PR, Fenical W (1994) Strategies for the discovery of secondary metabolites from marine bacteria: ecological perspectives. Annu Rev Microbiol 48:559-584

Johnson JL (1994) Similarity analysis of rRNAs, In: Gerhardt P, Murray RGE, Wood WA, Krieg NR (eds) Methods for general and molecular bacteriology. Am Soc Microbiol, Washington, DC, p 683-700

Jones GP, McCormick MI, Srinivasan M, Eagle JV (2004) Coral decline threatens fish biodiversity in marine reserves. Proc Natl Acad Sci USA 25, 101(21):8251-8253

Jukes TH, Cantor CR (1969) Evolution of protein molecules. In: Munro N (ed) Mammalian protein metabolism. Academic Press, New York, p 21-132

Kamanavalli CM, Ninnekar HZ (2004) Biodegradation of DDT by a Pseudomonas species. Curr Microbiol 48:10-13

Kim JH, Wei ZM, Beer SVJ (1997) The hrpA and hrpC operons of Erwinia amylovora encode components of a type III pathway that secretes harpin. Bacteriol 179:1690-1697

Kobayashi T, Imai M, Ishitaka Y, Kawaguchi Y (2004) Histopathological studies of bacterial haemorrhagic ascites of ayu, Plecoglossus altivelis (Temminck \& Schlegel). J Fish Dis 27:451-457

Koch R (1882) Source book of medical history. Dover, New York, p 392-406

Lapointe B, Clark M (1992) Nutrient inputs from the watershed and coastal eutrophication in the Florida Keys. Estuaries 15:465-476

Lereclus D, Delecluse A, Lecadet MM (1993) Diversity of Bacillus thuringiensis toxins and genes. In: Entwistle PF, Cory JS, Bailey MJ, Higgs S (eds) Bacillus thuringiensis, an environmental biopesticide: theory and practice. John Wiley \& Sons, Chichester, p 37-69

Lodeiros C, Freites L, Velez A (1992) Bacillary necrosis in larvae of the bivalve Euvola ziczac (Linnaeus, 1758) caused by a Pseudomonas sp. Acta Cient Venez 43:154-158

Lorenz MG, Sikorski J (2000) The potential for intraspecific horizontal gene exchange by natural genetic transformation: sexual isolation among genomovars of Pseudomonas stutzeri. Microbiology 12:3081-3090

Luz AP, Pellizari VH, Whyte LG, Greer CW (2003) A survey of indigenous microbial hydrocarbon degradation genes in soils from Antarctica and Brazil. Can J Microbiol 50: 323-333

Madigan M, Martinko J, Parker J (1997) Brock biology of microorganisms, 8th edn. Prentice Hall, Princeton, NJ

Ouoba LI, Cantor MD, Diawara B, Traore AS, Jakobsen M (2003) Degradation of African locust bean oil by Bacillus subtilis and Bacillus pumilus isolated from soumbala, a fermented African locust bean condiment. J Appl Microbiol 95:868-873

Pedley KF, Martin GB (2004) Identification of MAPKs and their possible MAPK kinase activators involved in the Pto-mediated defense response of tomato. J Biol Chem 279:49229-49235

Porter JW, Dustan P, Jaap WC, Wheaton JL and 5 others (2001) Patterns of spread of coral disease in the Florida Keys. Hydrobiologia 460:1-24

Richardson L (1996) Horizontal and vertical migration patterns of Phormidium corallyticum and Beggiatoa spp. associated with black-band disease of corals. Microb Ecol 32:323-335

Ritchie KB, Polson SW, Smith GW (2001) Microbial disease causation in marine invertebrates: problems, practices, and future prospects. Hydrobiologia 460:131-139

Rützler K (1988) Mangrove sponge disease induced by cyanobacterial symbionts: failure of a primitive immune system? Dis Aquat Org 5:143-149

Saitou N, Nei M (1987) The neighbor-joining method: a new method for reconstructing phylogenetic trees. Mol Biol Evol 4:406-425

Smith GW, Ives LD, Nagelkerken I, Ritchie IA, Ritchie KB (1996) Aspergilliosis associated with Caribbean Sea fan mortalities. Nature 382:487

Syed RA, Shah J (1976) Some important aspects of insect pest management in oil palm estates in Sabah, Malaysia. In: Earp DA, Newall W (eds) International developments in oil palm. Incorporated Society of Planters, Kuala Lumpur, p $577-590$

Vacelet J (1994) Control of the severe sponge epidemic - Near East and Europe: Algeria, Cyprus, Egypt, Lebanon, Malta, Morocco, Syria, Tunisia, Turkey, Yugoslavia, technical report: the struggle against the epidemic which is decimating Mediterranean sponges, FI:TCP/RAB/8853, FAO, Rome, p 1-39

Wang Y, Guo J, Liu R (2001). Biosorption of heavy metals by bacteria isolated from activated sludge. Huan Jing Ke Xue 22:72-75

Webster NS, Negri AP, Webbb RI, Hill RT (2002) A sponginboring $\alpha$-proteobacterium is the etiological agent of disease in the Great Barrier Reef sponge Rhopaloeides odorabile. Mar Ecol Prog Ser 232:305-309

Wei ZM, Beer SVJ (1995) hrpL activates Erwinia amylovora hrp gene transcription and is a member of the ECF subfamily of sigma factors. Bacteriol 177:6201-6210

Weidner S, Arnold W, Puhler A (1996) Diversity of uncultured microoranisms associated with the seagrass Halophila stipulacea estimated by restriction fragment length polymorphism analysis of PCR-amplified 16S rRNA genes. Appl Environ Microbiol 62:766-771

Willis DK, Holmstadt JJ, Kinscherf TG (2001) Genetic evidence that loss of virulence associated with gacS or gacA mutations in Pseudomonas syringae B728a does not result from effects on alginate production. Appl Environ Microbiol 67:1400-1403

Wulff JL (2000) Rapid, pathogen-caused shifts in coral reef sponge community composition. 9th Int Coral Reef Symp, Abstract, p 84

Xie GL, Soad A, Swings J, Mew TW (2003) Diversity of Gram negative bacteria antagonistic against major pathogens of rice from rice seed in the tropic environment. J Zhejiang Univ Sci 4:463-468

Yumoto I, Hirota K, Sogabe Y, Nodasaka Y, Yokota Y, Hoshino T (2003) Psychrobacter okhotskensis sp. nov., a lipase-producing facultative psychrophile isolated from the coast of the Okhotsk Sea. Int J Syst Evol Microbiol 6:1985-1989

Submitted: September 5, 2005; Accepted: March 13, 2006 Proofs received from author(s): September 18, 2006 